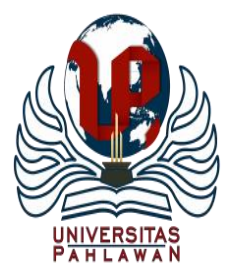

Edukatif : Jurnal Ilmu Pendidikan Volume 3 Nomor 1 Tahun 2021 Halm 255 - 260

EDUKATIF: JURNAL ILMU PENDIDIKAN

Research \& Learning in Education

https://edukatif.org/index.php/edukatif/index

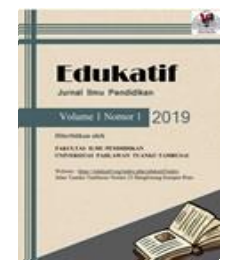

\title{
Analisis Situasi Pembelajaran IPA Sekolah Dasar dengan Metode Daring Selama Masa Wabah Covid-19
}

\author{
${\text { Fitriani } B^{1 凶} \text {, Eka Safitri Sari Ramli }}^{2}$ \\ Universitas Muhammadiyah Buton, Indonesia ${ }^{1,2}$

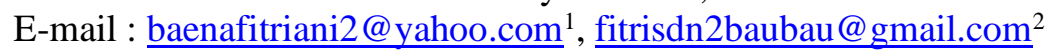

\begin{abstract}
Abstrak
Penelitian ini bertujuan untuk mengetahui situasi pembelajaran IPA siswa sekolah dasar dengan metode Pembelajaran Daring selama masa wabah Covid-19. Desain penelitian yang digunakan adalah kualitatif deskriptif, data diperoleh melalui wawancara dan observasi. Subjek penelitian ini adalah Guru dan siswa SDN 2 Bataraguru. Hasil penelitian menunjukkan bahwa perubahan metode pembelajaran seperti metode ceramah, metode diskusi, tanya jawab, eksperimen, demontrasi yang dilakukan secara langsung tatap muka oleh guru dengan peserta didik menjadi pembelajaran dengan menggunakan metode daring akibat pandemi Covid-19 menimbulkan masalah baru dalam proses belajar mengajar diantaranya, situasi pembelajaran kurang efektif, sulitnya guru dalam menyampaikan materi yang dikombinasikan dengan praktikum ,serta materi dengan perhitungan, keterbatasan orang tua peserta didik dalam membeli paket data dan jaringan kurang bagus. Selanjutnya dalam menangani beberapa hambatan tersebut pada pelajaran IPA, guru SD Negeri 2 Bataraguru melaksanan sistem kunjungan kerumah para peserta didik, memberikan materi secara bertahap dengan bahasa yang mudah dimengerti oleh peserta didik sehingga membantu peserta didik untuk memahami materi pelajaran IPA.
\end{abstract}

Kata Kunci: situasi pembelajaran IPA SD, Metode daring.

\begin{abstract}
This study aims to determine the situation of elementary school students' science learning through the Online Learning method during the Covid-19 outbreak. The research design used is descriptive qualitative, data obtained through interviews and observations. The subjects of this study were teachers and students of SDN 2 Bataraguru. The results showed that changes in learning methods such as lecture methods, discussion methods, question and answer, experiments, demonstrations carried out face-to-face by teachers with students became learning using online methods due to the Covid-19 pandemic results in new problems in the teaching and learning process including, the learning situation is less effective, the difficulty of the teachers in delivering material combined with practicum, as well as material with calculations, the limitations of the parents of students in buying internet quota, and bad internet network. Furthermore, in dealing with some of these obstacles in science lessons, the teachers of SD Negeri 2 Bataraguru carry out home visits system for students, providing gradual material with language that is easily understood by the students to help them understand science lesson.
\end{abstract}

Keywords: Elementary School Natural Science learning situation, Online method.

Copyright (c) 2021 Fitriani.B, Eka Safitri Sari Ramli

$\triangle$ Corresponding author

Email : baenafitriani2@yahoo.com

DOI : https://doi.org/10.31004/edukatif.v3i2.326

ISSN 2656-8063 (Media Cetak)

ISSN 2656-8071 (Media Online)

Edukatif : Jurnal Ilmu Pendidikan Vol 3 No 1 Tahun 2021 p-ISSN 2656-8063 e-ISSN 2656-8071 
256 Analisis Situasi Pembelajaran IPA Sekolah Dasar dengan Metode Daring Selama Masa Wabah Covid19 - Fitriani B, Eka Safitri Sari Ramli

DOI : https://doi.org/10.31004/edukatif.v3i2.326

\section{PENDAHULUAN}

Di dunia saat ini sedang berjuang melawan wabah Coronavirus Disease (COVID-19). Covid-19 disebabkan oleh SARS-COV2 yang termasuk dalam keluarga besar corona virus yang sama dengan penyebab SARS pada tahun 2003 hanya berbeda jenis virusnya. Pada 30 Januari 2020 WHO menetapkan wabah Covid19 sebagai darurat kesehatan masyarakat yang menjadi perhatian secara internasional karena menimbulkan resiko tinggi terutama bagi negara-negara dengan sistem pelayanan kesehatan yang rentan (Firman, 2020). Menurut Aljazeera (7/7/2020), penyakit ini menyebabkan lebih dari 11,4 juta infeksi di 188 negara dan lebih dari 6,1 juta orang telah sembuh dari virus corona.Pada tanggal 2 Maret 2020, Indonesia melaporkan 2 orang terkonfirmasi positif Covid-19 yang merupakan kasus pertama.(Anggraeni, 2020).

Dengan adanya virus Covid-19 di Indonesia saat ini sangat berdampak bagi seluruh masyarakat. Menurut kompas, 28/03/2020 dampak virus Covid-19 terjadi diberbagai bidang seperti sosial, ekonomi, pariwisata dan pendidikan. Pada tanggal 18 Maret 2020 menurut surat edaran yang dikeluarkan pemerintah bahwa segala kegiatan didalam dan diluar ruangan untuk sementara ditunda dulu demi mengurangi penyebaran Corona terutama dalam bidang pendidikan. Pada tanggal 24 Maret 2020 Menteri pendidikan dan Kebudayaan Republik Indonesia mengeluarkan surat edaran Nomor 4 Tahun 2020 tentang pelaksanaan Kebijakan Pendidikan Dalam Masa Darurat Penyebaran COVID, dalam Surat edaran tersebut dijelaskan bahwa proses belajar mengajar dilaksanakan di rumah melalui pembelajaran daring jarak jauh. (Octavio et al., 2020).

Kota Baubau juga termasuk daerah yang mengharuskan peserta didik pada seluruh jenjang satuan pendidikan untuk belajar dari rumah. Hal ini dikarenakan pada bulan Juni tahun 2020 berdasarkan media online RRI.co.id Kota Baubau berada pada zona merah, sesuai dengan keputusan bersama (SKB) 4 menteri tentang panduan penyelenggaraan pembelajaran pada tahun ajaran 2020/2021 di masa pandemi Corona Virus Disease 2019 ( COVID-19), bahwa satuan pendidikan yang berada pada wilayah zona merah harus melaksanakan kegiatan belajar dari rumah.(Wataullah, 2020).

Sistem pembelajaran daring adalah implentasi pendidikan jarak jauh pada pendidikan jarak jauh pada pendidikan tinggi yang bertujuan untuk meningkatkan pemerataan akses terhadap pembelajaran yang bermutu.(Napsawati, 2020). Pembelajaran daring lebih menitikberatkan pada kecermatan dan kejelian peserta didik dalam menerima dan mengolah informasi yang diberikan secara online .(Rahmawati, Novi Rosita, Rosida, Fatimatul Eva, Kholidin, 2020).

Pembelajaran yang dilaksanakan pada sekolah dasar juga menggunakan pembelajaran daring/jarak jauh dengan melalui bimbingan orang tua. Dengan pembelajaran daring siswa memiliki keleluasan waktu belajar, dapat belajar kapanpun dan dimanapun. Siswa dapat berinteraksi dengan guru menggunakan beberapa aplikasi seperti classroom, Video converence, Zoom maupun melalui whatshaap group (Dewi, 2020). Selama pembelajaran daring berlangsung banyak orang tua yang mengeluhkan beberapa masalah yang dihadapi selama peserta didik belajar dirumah, diantaranya terlalu banyak tugas yang diberikan dan guru yang belum mengoptimalkan teknologi. Disamping banyaknya keluhan orang tua mengenai pembelajaran daring, namun ternyata pembelajaran juga memiliki beberapa kelebihan. Adapun beberapa kelebihan dari pembelajaran daring yaitu adanya keluwesan waktu dan tempat belajar, misalnya belajar dapat dilakukan di kamar, ruang tamu dan sebagainya serta waktu yang diseseuaikan misalnya pagi, siang, sore atau malam. Dapat mengatasi permasalahan mengenai jarak, misalnya peserta didik tidak harus pergi ke sekolah dahulu untuk belajar. Tidak ada batasan dan dapat mencakup area yang luas. disamping ada beberapa kelebihan dari pembelajaran daring, namun adapun kekurangan dari pembelajaran daring. Menurut Meidawati (dalam Yunitasari \& Hanifah, 2020) Pembelajaran daring mempuyai banyak manfaat, yang pertama dapat membangun komunikasi dan diskusi yang sangat efisien antara guru dengan murid, kedua siswa saling berinteraksi dan berdiskusi antara siswa 
257 Analisis Situasi Pembelajaran IPA Sekolah Dasar dengan Metode Daring Selama Masa Wabah Covid19 - Fitriani B, Eka Safitri Sari Ramli

DOI : https://doi.org/10.31004/edukatif.v3i2.326

yang satu dengan yang lainnya tanpa melalui guru, ketiga dapat memudahkan interaksi antara siswa guru, dengan orang tua, keempat sarana yang tepat untuk ujian maupun kuis, kelima guru dapat dengan mudah memberikan materi kepada siswa berupa gambar dan vidio selain itu murid juga dapat mengunduh bahan ajar tersebut, keenam dapat memudahkan guru membuat soal dimana saja dan kapan saja. Adapun beberapa kekurangan yang terjadi pada pembelajaran daring yaitu peserta didik kurang fokus pada pembelajaran karena suasana rumah yang kurang kondusif. Keterbatasan paket internet yang menjadi penghubung dalam pembelajaran.

Kelemahan dari sistem pembelajaran daring ialah sulit menemukan titik fokus anak karena situasi dan kondisi rumah kurang mendukung untuk proses pembelajaran daring. Kurangnya interaki antara peserta didik dengan guru dan mengakibatkan peserta didik lebih sulit memahami materi pembelajaran (Rahmawati 2020). Berdasarkan pada permasalahan yang telah dijelaskan, maka peneliti terdorong untuk memberikan gambaran mengenai situasi pembelajara IPA siswa sekolah dasar dengan metode daring selama masa wabah Covid-19.

\section{METODE PENELITIAN}

Desain penelitian yang digunakan adalah kualitatif deskriptif. Pendekatan kualitatif menurut Bogdan dan Taylor dalam (Arifin, 2012) adalah prosedur Penelitian yang menghasilkan data deskriptif berupa kata-kata tertulis atau lisan dari orang-orang dan perilaku yang dapat diamati. Berdasarkan pada jenis permasalahan yang dibahas dalam penelitian ini, maka peneliti menggunakan pola penelitian kualitatif deskriptif. Menurut (Arikunto, 2013) penelitian deskriptif adalah penelitian yang dimaksudkan untuk menyelidiki keadaan, kondisi atau hal lain-lain yang sudah disebutkan, yang hasilnya dipaparkan dalam bentuk laporan penelitian. Penelitian dilaksanakan di sekolah Dasar Negeri 2 Bataraguru Jl. Budi Utomo No. 16B, Bataraguru, Kec. Wolio, Kota Baubau Prov. Sulawesi Tenggara. Subjek penelitian ini adalah Beberapa peserta didik SD Negeri 2 Bataraguru dan Guru Mata pelajaran IPA SD Negeri 2 Bataraguru. Adapun teknik pengumpulan data yang digunakan dalam penelitian ini melalui: wawancara, observasi.

Teknik analisis data yang digunakan peneliti merupakan teknik analisis Miles and Huberman. Miles and Huberman (dalam Sugiono, 2015) mengemukakan bahwa aktivitas dalam analisis data kualitatif dilakukan secara interaktif dan berlangsung secara terus menerus sampai tuntas, sehingga datanya sudah jenuh. Terdapat tiga aktivitas dalam analisis data yaitu, data reduction, data display, dan conclusion drawing/verivication. Pada tahap data reduction data yang diperoleh di lapangan jumlahnya cukup banyak, untuk itu perlu dicatat secara teliti dan rinci. Mereduksi data berarti merangkum, memilih hal-hal yang pokok, memfokuskan pada hal-hal yang penting, dicari tema dan polanya dan membuang yang tidak perlu. Data yang telah direduksi akan memberikan gambaran yang lebih jelas, dan mempermudah peneliti untuk melakukan pengumpulan data selanjutnya, dan mencarinya bila diperlukan (Sugiono, 2015). Pada tahap data display bertujuan agar memudahkan peneliti untuk memahami apa yang terjadi, serta dapat merencanakan langkah selanjutnya berdasarkan apa yang telah dipahami tersebut. Tahap yang terakhir conclusion drawing/verivication dalam penelitian kualitatif mungkin dapat menjawab rumusan masalah yang dirumuskan di awal atau juga mungkin tidak. Hal tersebut terjadi karena penelitian kualitatif masih bersifat sementara dan akan berkembang setelah penelitian berada di lapangan.

\section{HASIL DAN PEMBAHASAN PENELITIAN}

Berdasarkan hasil wawancara dengan beberapa guru kelas IV, V, dan VI pada pembelajaran IPA SD Negeri 2 Bataraguru diperoleh informasi sebagai berikut: Proses pembelajaran daring pada pelajaran IPA awalnya menggunakan aplikasi zoom, karena keterbatasan dana dari beberapa peserta didik untuk membeli 
258 Analisis Situasi Pembelajaran IPA Sekolah Dasar dengan Metode Daring Selama Masa Wabah Covid19 - Fitriani B, Eka Safitri Sari Ramli

DOI : https://doi.org/10.31004/edukatif.v3i2.326

paket, sehingga aplikasi yang digunakan adalah whatsapp group, Penggunaan aplikasi whatsapp group menurut guru pada pembelajaran IPA membuat peserta didik ada yang aktif dan ada juga yang tidak aktif, guru kesulitan dalam menjelaskan materi pembelajaran IPA yang terdapat praktikum dan materi yang berhubungan dengan lingkungan, juga materi yang terdapat perhitungannya kepada peserta didik secara daring, peserta didik kurang mengerti dengan materi yang dikombinasikan dengan praktikum, masih terdapat peserta didik yang tidak mengerjakan tugas secara online dengan tepat waktu, dalam proses pembelajaran daring ada beberapa siswa yang di dampingi orang tua dan ada juga yang tidak didampingi dan guru lebih menyukai pembelajaran tatap muka daripada pembelajaran online.

Berdasarkan tanggapan peserta didik SD Negeri 2 Bataraguru diperoleh informasi sebagai berikut: Pembelajaran daring dilakukan menggunakan aplikasi whatsapp group. Peserta didik kesulitan dalam memahami pembelajaran IPA yang dikombinasikan dengan praktikum dan lingkungan. Dengan metode daring, peserta didik mengalami kesulitan dalam mengaur waktu belajar karena banyak aktivitas lain yang dilakukan selain belajar. Peserta didik memiliki motivasi belajar yang rendah, sehingga dalam pengumpulan tugas sering diabaikan dan Para peserta didik lebih menyukai pembelajaran tatap muka dibandingkan pembelajaran daring.

Berdasarkan hasil penelitian yang diperoleh dari beberapa informan menunjukkan bahwa metode daring ditengah masa pandemi Covid-19 khususnya pada pelajaran IPA terdapat beberapa masalah yang dialami oleh guru dan peserta didik. Hal ini disebabkan oleh kurangnya dipahami materi pelajaran IPA yang dikombinasikan dengan praktikum dan lingkungan tanpa melalui pembelajaran tatap muka/ angsung antara guru dan peserta didik. Sulitnya menyampaikan materi berupa rumus-rumus dan cara perhitungannya, melakukan praktikum yang dirasakan oleh guru. Kesulitan tersebut juga dirasakan oleh para peserta didik. Selaras dengan penelitian yang dilakukan oleh Purwanto bahwa pembelajaran daring merupakan sesuatu yang baru bagi guru. Dengan adanya metode pembelajaran jarah jauh membuat para guru perlu waktu untuk beradaptasi dan mereka menghadapi perubahan baru yang secara tidak langsung akan mempengaruhi kualitas hasil belajar (Purwanto et al., 2020). Dan ini juga diperkuat oleh penelitian Adriana yang menyatakan bahwa pelaksanaan pembelajaran IPA di masa covid-19 dengan menggunakan 3 metode pembelajaran tidak menjadikan pembelajaran menjadi efektif, tetap dengan menggunakan pembelajaran daring tidak bisa menjadikan siswa memahami konsep pada pembelajaran IPA serta pembelajaran IPA membutuhkan suatu percobaan yang memungkinkan dilaksanakannya secara langsung atau tatap muka. (Adriana, Encep, Ramadayanti, Suci, Noviyanti, 2020).

Hasil wawancara dengan informan juga menunjukkan bahwa pembelajaran daring, situasi pembelajaran IPA kurang efektif, selain sulitnya menyampaikan materi oleh guru dan susahnya memahami materi oleh peserta didik. Masalah lainnya yang dihadapi oleh guru dan siswa adalah jaringan yang kadangnya terputus sehingga menyebabkan proses belajar mengajar terhambat. Selain faktor jaringan, keterbatasan orangtua siswa untuk membeli paket internet karena menurut guru bahwa kebanyakan orangtua siswa berada di ekonomi menengah.

Dari berbagai faktor, salah satu cara yang diterapkan oleh guru pada pelajaran IPA agar proses pembelajaran tetap berlangsung dan tidak memberatkan peserta didik yaitu guru melakukan sistem kunjungan kerumah peserta didik dengan menerapkan protokol kesehatan, dengan menerapkan kunjungan tersebut peserta didik akan labih leluasa bertanya ke gurunya tentang pelajaran IPA yang tidak dimengerti. Adapun hambatan-hambatan yang dihadapi oleh guru pada pelajaran IPA, guru tetap berusaha memberikan yang terbaik kepada peserta didiknya agar tetap menerima materi meskipin tidak maksimal ketika proses pmbelajaran tatap muka disekolah. Salah satu caranya dengan memberikan materi secara bertahap dengan menggunakan bahasa yang sederhana yang mudah dimengerti oleh peserta didik, dan dalam pemberian tugas guru memberikan tenggang waktu yang sesuai dengan kemampuan peserta didik. 
259 Analisis Situasi Pembelajaran IPA Sekolah Dasar dengan Metode Daring Selama Masa Wabah Covid19 - Fitriani B, Eka Safitri Sari Ramli

DOI : https://doi.org/10.31004/edukatif.v3i2.326

Pada situasi pembelajaran yang dirasakan oleh peserta didik dalam menggunaka metode daring ini tidak efektif dibandingkan dengan pembelajaran langsung di sekolah. Hal ini dibuktikan beberapa informasi dari peserta didik bahwa meraka sulit memahami materi yang dikombinasikan dengan praktikum dan materi yang dikaitkan dengan perhitungan. Selanjutnya menurut peserta didik SD Negeri 2 Bataraguru proses pembelajaran daring terganggu dengan kegiatan lain yang tak terduga dirumah. Misal para peserta didik selalu bermain game online sehingga kegiatan tersebut sangat mengganggu konsentrasi proses pembelajaran daring. Dari berbagai gambaran mengenai hambatanyang dihadapi oleh guru dan peserta didik dalam pembelajaran daring menunjukkan bahwa pembelajaran langsung tatap muka dikelas lebih efektif dibandingkan pembelajaran jarak jauh tanpa tatap muka secara langsung.

\section{KESIMPULAN}

Berdasarkan informasi menunjukkan bahwa perubahan metode pembelajaran seperti metode ceramah, metode diskusi, tanya jawab, eksperimen, demontrasi yang dilakukan secara langsung tatap muka oleh guru dengan peserta didik menjadi pembelajaran dengan menggunakan metode daring akibat pandemi Covid-19 menimbulkan masalah baru dalam proses belajar mengajar diantaranya, situasi pembelajaran kurang efektif, sulitnya guru dalam menyampaikan materi yang dikombinasikan dengan praktikum, serta materi dengan perhitungan, keterbatasan orang tua peserta didik dalam membeli paket data dan jaringan kurang bagus.

Selanjutnya dalam menangani beberapa hambatan tersebut pada pelajaran IPA, guru SD Negeri 2 Bataraguru melaksanan sistem kunjungan kerumah para peserta didik, memberikan materi secara bertahap dengan bahasa yang mudah dimengeri oleh peserta didik sehingga membantu perserta didik untuk memahami materi pelajaran IPA.

\section{UCAPAN TERIMA KASIH}

Terimakasih kepada Rekor Universitas Muhammadiyah Buton (UM Buton), Dekan Fakultas Keguruan dan Ilmu Pendidikan (FKIP) Universitas Muhammadiyah Buton dan Ketua Program Studi Pendidikan Guru Sekolah Dasat FKIP UM Buton yang sudah mendukung dan memfasilitasi penulis sehingga artikel ini dapat terselesaikan. Terimakasih kepada Tim Jurnal Ilmu Pendidikan yang sudah bersedia menerima artikel ini untuk diterbitkan.

\section{DAFTAR PUSTAKA}

Adriana, Encep, Ramadayanti, Suci, Noviyanti, T. esti. (2020). PEMBELAJARAN IPA DI SD PADA MASA COVID 19. Prosiding Seminar Nasional Pendidikan FKIP, 3(1), 409-413.

Anggraeni, N. (2020). Larangan Impor Hewan dari China Terkait Pencegahan Penyebaran Covid-19. Muamalatuna, 12(1), 1. https://doi.org/10.37035/mua.v12i1.3299

Arifin, Z. (2012). Penelitian Pendidikan. PT Rosdakarya.

Arikunto, S. (2013). Prosedur Penelitian Suatu Pendekatan Praktik. PT. Rineka Cipta.

Dewi, W. A. F. (2020). Dampak COVID-19 terhadap Implementasi Pembelajaran Daring di Sekolah Dasar. Edukatif: Jurnal Ilmu Pendidikan, 2(1), 55-61. https://doi.org/10.31004/edukatif.v2i1.89

Napsawati, N. (2020). Analisis Situasi Pembelajaran Ipa Fisika Dengan Metode Daring Di Tengah Wabah Covid-19. Karst : JURNAL PENDIDIKAN FISIKA DAN TERAPANNYA, 3(1), 96-102. https://doi.org/10.46918/karst.v3i1.546 
260 Analisis Situasi Pembelajaran IPA Sekolah Dasar dengan Metode Daring Selama Masa Wabah Covid19 - Fitriani B, Eka Safitri Sari Ramli

DOI : https://doi.org/10.31004/edukatif.v3i2.326

Octavio, A. E., Teknik, F., Alfara, M., \& Teknik, F. (2020). Belajar dirumah dengan Berdampingan covid 19 pada Anak-anak Usia Sekolah Dasar. 5202417036.

Purwanto, A., Pramono, R., Asbari, M., Santoso, P. B., Wijayanti, L. M., Choi, C. H., \& Putri, R. S. (2020). Studi Eksploratif Dampak Pandemi COVID-19 Terhadap Proses Pembelajaran Online di Sekolah Dasar. EduPsyCouns: Journal of Education, Psychology and Counseling, 2(1), 112. https://ummaspul.e-journal.id/Edupsycouns/article/view/397

Rahmawati, Novi Rosita, Rosida, Fatimatul Eva, Kholidin, F. I. (2020). SITTAH: Journal of Primary Education, Vol. 1 No. 2, Oktober 2020. 1(2), 139-148.

Sugiono. (2015). Metode Penelitian Pendidikan (Pendekatan Kuantitatif, Kualitatif, dan R\&D). CV Alfabeta.

Wataullah, H. M. (2020). Masih di Zona Merah, Dikbud Baubau Tetap Melajutkan Belajar Daring. $R R I$ Kendari. https://www.google.com/search?q=pada+bulan+Juni+tahun+2020+berdasarkan+media+online +RRI.co.id+Kota+Baubau+berada+pada+zona+merah\&biw=1366\&bih=657\&ei=yzVtYJSbL8 2srQHNrIsg\&oq=pada+bulan+Juni+tahun+2020+berdasarkan+media+online+RRI.co.id+Kota + Baubau+berada $+p$

Yunitasari, R., \& Hanifah, U. (2020). Pengaruh Pembelajaran Daring terhadap Minat Belajar Siswa pada Masa COVID 19. Edukatif: Jurnal Ilmu Pendidikan, 2(3), 236-240. 